\title{
Um guia à logística
}

Em sua terceira edição, a obra trata, conjuntamente, do papel estratégico da logística, de direcionadores estratégicos-chave para seu desempenho e das ferramentas e técnicas para análise da cadeia logística. 0 principal diferencial da obra ésua extensa base analítica e ferramental.

\section{por LuizArtur Ledur Brito FGVEAESP}

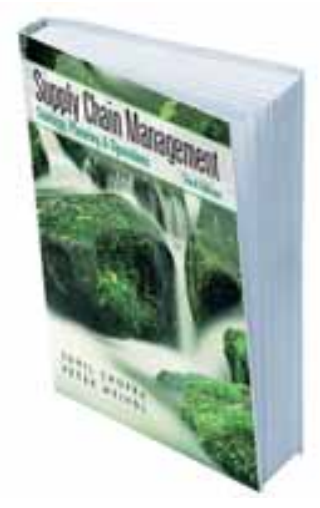

Supply chain management Sunil Chopra e Peter Meind PrenticeHall, 2006, 552p
O livro de Chopra e Meindl foi desenvolvido a partir do curso de supply chain management ministrado por Sunil Chopra aos alunos do segundo ano do MBA da Kellog School of Management, da Northwestern University. Apesar desta concepção mais voltada para a temática de pós-graduação, o livro pode ser usado em um curso de graduação avançado no tema.

O maior diferencial da obra em relação à grande quantidade de livros sobre supply chain management é a sua abordagem quantitativa e instrumental, que vai muito além das generalidades normalmente repetidas em muitos dos demais textos. Os exercícios e exemplos fazem um uso intensivo de Excel avançado e requerem bastante esforço e dedicação do leitor.

A idéia central dos autores é que a compreensão e análise estratégica do supply chain necessita de uma fundamentação analítica e instrumental, dando ao leitor um entendimento mais sólido e profundo dos princípios e evitando a superficialidade e o lugar comum.

Os pontos mais fortes do livro são justamente os capítulos em que os au- tores exploram a análise quantitativa em profundidade. Destacam-se, neste aspecto, a segunda, terceira e quarta partes do livro.

A segunda parte (capítulos 4, 5 e 6), especificamente, é dedicada a várias questões de configuração de redes, quando então se faz o uso da rotina "Solver", do Excel, e de árvores de decisão para a solução de vários problemas. A discussão teórica poderia ser mais aprofundada, mas os exemplos e exercícios dão condições aos al unos de discutir com muito mais propriedade e sensibilidade os temas propostos.

A terceira parte (capítulos 7, 8 e 9) explora vários métodos de previsão de demanda e problemas de planejamento agregado. Os vários métodos de previsão de demanda são simulados em planilhas Excel, demandando compreensão do leitor da mecânica dos cálculos. 0 exemplo desenvolvido ao longo do capítulo 7 é, contudo, infeliz. É um exemplo com sazonalidade que é aplicado aos vários métodos, incluindo os que não são adequados para sazonalidade. Embora com correção matemática, a abordagem não é didática. Os capítulos 8 e 9 usam a rotina 
"Solver" para a solução de problemas de planejamento agregado e são extremamente didáticos e fáceis de seguir. São excelentes capítulos que permitem uma ligação com outras disciplinas de administração como o marketing.

A quarta parte (capítulos 10, 11 e 12) faz talvez a maior contribuição do livro em relação aos demais textos. Estes capítulos cobrem o tema de gestão de estoques de uma forma detalhada e quantitativa. A didática e clareza poderiam ser aperfeiçoadas em vários pontos com uma melhor seleção dos valores dos exemplos e sua ordenação, mas para o aluno mais dedicado isto não é uma dificuldade tão grande.

Se, de um lado, temos de reconhecer que, na abordagem quantitativa do tema, o livro marca importante contribuição, de outro, na parte teórica, há necessidade de um aprofundamento maior em termos de conteúdo. N esse aspecto, em particular, o livro pode melhorar, seja por meio de maior abrangência, exemplos práticos, casos e de uma didática mais clara.

Contudo, em nossa perspectiva, essa limitação pode ser facilmente compensada se o leitor complementar esta leitura com a de textos, casos e artigos mais tradicionais.

Como um todo, este é um livro com um conteúdo desafiante, sendo, por essa razão, mais bem apreendido e utilizado se combinado à orientação de um instrutor. Adicionalmente, este instrutor terá de lançar mão de recursos computacionais durante as aulas.

Por fim, os materiais de apoio são bastante razoáveis, especialmente a disposição de planilhas para desenvolvimento dos exemplos e soluções de exercícios. Como recomendação final, val ea pena re-enfatizar o fato de que um professor que deseje adotar o livro deverá preparar-se para um bom trabalho de estudo e familiarização prévios com essa obra de Chopra e Meindl.

Luiz Artur Ledur Brito

Doutor em Administração pela FGV-EAESP

Prof. do Departamento de Produção e Operações Industriais da FGV-EAESP

E-mail: Luiz.Brito@fgv.br

\section{II maior diferencial da obra em relação à grande quantidade de livros sobre supply chain management é a sua abordagem quantitativa e ferramental, a qual vai muito além das generalidades normalmente repetidas em muitos dos demais textos.}

